\title{
Łączność skazanych ze światem zewnętrznym - kontakty poza murami zakładu karnego
}

\section{Connection of convicts with the outside world - contacts outside the prison walls}

\section{STRESZCZENIE}

Celem niniejszego artykułu jest analiza wybranych rozwiązań normatywnych, zawartych w aktualnie obowiązującym kodeksie karnym wykonawczym, które służyć mają podtrzymywaniu kontaktów osadzonych ze światem zewnętrznym. Spośród całej gamy instrumentów omówione zostały te, które umożliwiają skazanemu opuszczenie murów zakładu karnego. Omówiona została rola utrzymywania kontaktów z światem zewnętrznym, ze szczególnym uwzględnieniem więzi rodzinnych. Wskazane zostały również ewentualne niebezpieczeństwa wynikające z udzielania przepustek bądź zezwoleń na czasowe opuszczenie zakładu karnego, co pozwoliło w konsekwencji na postawienie postulatów de lege ferenda.

Słowa kluczowe: więźniowie, zakład karny, kontakt ze światem zewnętrznym

\section{WPROWADZENIE}

Aktywizacja skazanych w szerokim rozumieniu pełni wyjątkowo doniosłą rolę dla prawidłowego wykonywania kary pozbawienia wolności. Fundamentalnym celem systemu wykonywania kar jest umożliwienie skazanym prowadzenia odpowiedzialnego i wolnego od przestępstw życia (art. 67 k.k.w.)1. W kodeksie karnym wykonawczym wyrażono wprost zasadę poszanowania godności ludzkiej skazanych. Zgodnie z art. $4 \S 2$ k.k.w. skazani pomimo przebywania za murami zakładów karnych wciąż zachowują gwarantowane konstytucyjnie prawa i wolności

1 Ustawa z dnia 6 czerwca 1997 r. - Kodeks karny wykonawczy (Dz.U. z 2017 r., poz. 665 z późn. zm.). 
obywatelskie, a ich ograniczenie może wynikać tylko z ustawy oraz z wydanego na jej podstawie prawomocnego orzeczenia. Słusznie podkreśla się w literaturze, iż mówiąc o godności człowieka musimy mieć na względzie również godność osób skazanych $^{2}$. Istotnym elementem poszanowania godności człowieka jest umożliwienie realizacji potrzeby przynależności. Oczywistym jest, że już z istoty kary pozbawienia wolności wynikają pewne ograniczenia, w tym między innymi odseparowanie od rodziny, bliskich i dotychczasowego środowiska. Ustawodawca słusznie zatem dostrzega konieczność udzielenia skazanym, a także ich rodzinom niezbędnej pomocy (art. $41 \S 1$ k.k.w.). Wśród podstawowych instrumentów oddziaływania na skazanych znajduje się utrzymywanie kontaktów z rodziną i światem zewnętrznym (art. $67 \S 3$ k.k.w.). Warto wspomnieć, że ustawodawca zdecydował się w art. 102 pkt 2 k.k.w. wskazać expressis verbis, iż skazany ma prawo do utrzymywania więzi z rodziną i osobami bliskimi. Również w art. 105 § 1 k.k.w. eksponuje to prawo, stanowiąc, iż skazanemu należy umożliwiać utrzymywanie więzi z rodziną i innymi osobami bliskimi. Jest to tematyka szczególnie istotna i wymagająca stałej analizy, gdyż kontakty ze światem zewnętrznym między innymi zapobiegają prionizacji, tj. traktowaniu życia więziennego jako norma, z jednoczesnym lękiem przed życiem na wolności. Pozwalają ponadto na utrzymanie więzi rodzinnych, wpływają pozytywnie na stan psychiczny skazanych oraz pomagają w ich społecznej readaptacji ${ }^{3}$. Podejmując dyskusję nad skutecznymi metodami postępowania z osadzonymi nie można pominąć kwestii tak fundamentalnej jak więzi skazanego ze światem zewnętrznym. Istotną rolę pełnią w tym zakresie kontakty zarówno pośrednie w formie korespondencji, paczek, przekazów pieniężnych czy kontaktu telefonicznego ${ }^{4}$, jak również kontakty bezpośrednie, w formie widzeń, przepustek, zezwoleń na czasowe opuszczenie zakładu karnego oraz przerwy w wykonywaniu kary pozbawienia wolności. Problem ten jest wyjątkowo obszerny, dlatego ze względu na ograniczone ramy niniejszego opracowania bliższej analizie zostaną poddane tylko kontakty osadzonych w jednostkach penitencjarnych, do których dochodzi poza murami zakładu karnego. Wydają się one szczególnie istotne, gdyż stanowią swego rodzaju poddanie sprawcy próbie funkcjonowania w społeczeństwie bez

2 A. Zoll, Godność czlowieka jako źródło wolności i praw [w:] Hominum causa omne ius constitutum est. Księga jubileuszowa ku czci Profesor Alicji Grześkowiak, Lublin 2006, s. 284 i n.; M. Bielecki, Ochrona godności osoby skazanej w prawie karnym wykonawczym. Wybrane aspekty [w:] Zeszyty Naukowe KUL 60 (2018), nr 1.

3 E. Dawidziuk, Traktowanie osób pozbawionych wolności we wspótczesnej Polsce na tle standardów międzynarodowych, Warszawa 2013, s. 211.

4 W niektórych zakładach karnych osadzeni mają możliwość rozmowy z rodzinami za pośrednictwem komunikatora internetowego Skype. Ponadto, NSA w jednym z wyroków wskazuje, że fakt odbywania kary pozbawienia wolności w zakładzie karnym nie przesądza z góry, iż skazany jest pozbawiony dostępu do Internetu - korzystanie powinno być jednak zgodne z zasadami obowiązującymi w danym ośrodku (I OSK 730/12). 
naruszenia jego zasad. Analiza rozwiązań przyjętych na gruncie obecnego stanu prawnego prowadzi do wniosku, iż pożądana jest liberalizacja niektórych instytucji oraz wprowadzenie zmian, mających na celu zapewnienie szerszych niż dotychczas kontaktów skazanych z ich rodzinami i osobami bliskimi.

\section{PODTRZYMYWANIE KONTAKTÓW ZE ŚWIATEM ZEWNĘTRZNYM}

Pierwszą kwestią, którą należy poruszyć w tej części niniejszego opracowania jest wspomniana już we wstępie rola i znaczenie utrzymywania kontaktów z światem zewnętrznym. Przede wszystkim prawidłowo funkcjonująca rodzina daje jednostce możliwość rozwoju, zaspokajania różnorakich potrzeb, wprowadza w świat wartości i norm społecznych ${ }^{5}$. Daje poczucie stabilności, bezpieczeństwa oraz przynależności, stanowiąc mocną stronę procesu wychowawczego. Aby mogła trwać i dalej się rozwijać musi posiadać więź, której rozluźnienie lub zerwanie stwarza bez wątpienia problemy z odnalezieniem się poza murami zakładu karnego ${ }^{6}$. Utrzymanie omawianych więzi podczas wykonywania kary pozbawienia wolności daje osadzonemu poczucie, że zostanie on przyjęty do rodziny po powrocie na wolność. Świadomość, że ma się do czego wrócić odgrywa niezwykle istotną rolę w procesie jego społecznej readaptacji, stanowiąc ogromne wzmocnienie, dzięki czemu łatwiej jest uporać się z dolegliwościami, związanymi z izolacją więzienną. Wśród pierwszoplanowych celów utrzymywania tego rodzaju kontaktów wskazać więc należy podtrzymywanie spójności rodziny i więzi emocjonalnych z najbliższymi oraz dotychczasowym środowiskiem społecznej egzystencji ${ }^{7}$.

Ponadto, kontakty ze światem zewnętrznym pomagają złagodzić stres związany z karą pozbawienia wolności, szczególnie na początkowym etapie jej odbywania. To dzięki nim możliwe jest utrzymanie rozwoju jednostki na właściwym poziomie. Zaś, co wydaje się oczywiste, zerwanie więzi rodzinnych tudzież kontaktów z dotychczasowym środowiskiem może negatywne wpłynąć na proces resocjalizacji skazanego, powodując utratę motywacji do stania się lepszym. Utrzymywanie, a także umacnianie więzi skazanych $\mathrm{z}$ ich rodzinami oraz ze społeczeństwem, $\mathrm{w}$ tym

\footnotetext{
5 Szerzej zob. H. Machel, Rodzina skazanego jako wspótuczestnikjego resocjalizacji penitencjarnej, readaptacji i reintegracji społecznej, „Resocjalizacja Polska”, nr 7, 2014; D. Sarzała, Rodzina osoby przebywajacej w izolacji więziennej jako środowisko wsparcia społecznego, „Kwartalnik Naukowy”, 4(28)2016, A. Rzepliński, Wplyw wykonywania kary pozbawienia wolności na sytuacje rodzinną skazanego, Warszawa 1978; A. Rzepliński, Rodziny Więźniów dlugoterminowych, Instytut Państwa i Prawa, Wrocław 1981.

6 P. Wolińska, Znaczenie instytucji rodziny w życiu osób odbywających karę pozbawienia wolności, „Rozprawy Społeczne”, Tom X, Nr 2, 2016, s. 65.

7 T. Szymanowski, Prawo karne wykonawcze z elementami polityki karnej i penitencjarnej, Warszawa 2017, s. 321.
} 
między innymi stowarzyszeniami, fundacjami, instytucjami, które działają zgodnie z celami określonymi w Kodeksie karnym wykonawczym jest więc zasadniczym środkiem przeciwdziałania szkodliwym efektom uwięzienia. Zgodnie z postanowieniami Reguł Minimalnych i Europejskich Reguł Więziennych ${ }^{8}$ podtrzymywanie i rozwijanie kontaktów skazanego z rodziną i światem zewnętrznym jest niezbędne m.in. dla utrzymania łączących ich więzi oraz właściwej kondycji psychicznej osadzonych. Kontakty ze światem zewnętrznym ogrywają doniosłą rolę z punktu widzenia przygotowania osadzonych do opuszczenia murów zakładu karnego, bez względu na to czy mówimy o kontakcie bezpośrednim, czy też o kontakcie za pośrednictwem środków łączności. Okres pobytu w zakładzie karnym w znaczący sposób utrudnia nie tylko utrzymanie więzi rodzinnych, ale również koleżeńskich, dlatego tak istotne jest by należycie dbać o ich utrzymanie podczas wykonywania kary. Zgodzić należy się z poglądem B. Stańdo-Kaweckiej, iż „Bez pomocy rodziny, bez prac, bez mieszkania, bez oparcia w ludziach, którzy ułatwią pierwsze kroki na wolności, wychodzący z więzień w końcu wrócą do kolegów, którzy wyszli na wolność przed nimi’". Należy zwrócić uwagę na fakt, iż wyjście skazanego poza zakład karny umożliwi nie tylko kontakt z najbliższymi, ale przede wszystkim uczyni go odpowiedzialnym za swoje zachowanie. Zachowanie na wolności, poza kontrolą funkcjonariuszy Służby Więziennej, w miejscu, gdzie skazany musi sam dokonywać wyborów i ponosić za nie odpowiedzialność ${ }^{10}$. Godzi się zauważyć, że poza więziami rodzinnymi istotne są także te z osobami bliskimi, a więc związki towarzyskie i przyjacielskie. Każdy z nas w swoim życiu nawiązuje relacje z innymi członkami społeczności, które stanowią o miejscu jednostki w kręgu społecznym. W sytuacji, gdy człowiek na skutek popełnienia przestępstwa trafia do zakładu karnego dochodzi do rozluźnienia owych relacji, a nawet całkowitego ich zerwania. Osoba taka jest wówczas w bardzo trudnej dla niej sytuacji, gdyż przestaje pełnić wiele ról społecznych, nie ma możliwości decydowania o sobie, swoim czasie czy sposobie zaspokajania potrzeb, co w konsekwencji może powodować wiele niekorzystnych zjawisk dla prawidłowego rozwoju jednostki ${ }^{11}$. Z tych względów, na tyle, na ile jest to możliwe należy ograniczyć niekorzystny wpływ izolacji na skazanego oraz dążyć do normalizacji warunków życia w izolacji, co znajduje odzwierciedlenie m.in. we wspomnianych uprzednio Europejskich Regułach Więziennych, a do czego doskonałym instrumentem są poniżej analizowane

8 Zalecenia Rec (2006)2 Komitetu Ministrów do państw członkowskich Rady Europy w sprawie Europejskich Reguł Więziennych przyjęte przez Komitet Ministrów w dniu 11 stycznia 2006 r.

9 B. Stańdo-Kawecka, Pukanie do celi, „Forum Penitencjarne”, Nr 1, 2006, s. 11.

10 G.B. Szczygieł, Zezwolenie na czasowe opuszczenie zakładu karnego w polskim systemie penitencjarnym, Białystok 2013, s. 34.

${ }^{11}$ K. Linowski, Możliwości rozwoju człowieka w warunkach izolacji penitencjarnej poprzez utrzymanie kontaktów zewnętrznych, Acta Scientifica Academiae Osrtoviensis, „Prace Pedagogiczne”, 8/2001 s. 3 in. 
środki odziaływania penitencjarnego. Na marginesie niniejszych rozważań wskazać należy, że rozszerzaniu kontaktów więźniów z osobami spoza zakładów karnych, jak również możliwości czasowego ich opuszczania wiele uwagi poświęciły międzynarodowe standardy europejskie ${ }^{12}$.

\section{ROZWIĄZANIA PRZYJĘTE NA GRUNCIE PRAWA KARNEGO WYKONAWCZEGO}

Przechodząc do zagadnień bardziej szczegółowych, w pierwszej kolejności należy wskazać, że omówione poniżej formy kontaktu ze światem zewnętrznym, umożliwiające czasowe opuszczenie zakładu karnego są istotnym elementem systemu penitencjarnego, służącym realizacji celu wykonywania kary pozbawienia wolności. Są to formy najatrakcyjniejsze z perspektywy skazanych oraz najdalej idące, jeżeli chodzi o możliwość ich kontaktów ze światem zewnętrznym i jednocześnie najbardziej naturalne ${ }^{13}$. Ułatwiają one reintegrację społeczną i co najważniejsze stanowią ogromny wkład w stworzenie bardziej ludzkich więzień. Kodeks karny wykonawczy w brzmieniu aktualnie obowiązującym zna wiele form czasowego opuszczenia zakładu karnego. Co ważne, są to odrębne od siebie instytucje, posiadające jednak pewne cechy wspólne jak np. fakt, że czasu przebywania skazanego poza zakładem karnym na podstawie zezwoleń określonych w art. $138 \S 1$ pkt 7 lub 8, art. 141a, art. $165 \S 2$ k.k.w oraz przepustek z art. 91 pkt 7 i 92 pkt 9 k.k.w. co do zasady nie odlicza się od okresu odbywania kary. Ze względu na ograniczone ramy niniejszego opracowania nie sposób omówić wszystkich kompleksowo, jednak wskazane zostaną najistotniejsze zdaniem autorki kwestie.

Po pierwsze, dyrektor zakładu karnego może udzielić skazanemu zezwolenia na opuszczenie zakładu karnego w przypadkach szczególnie dla niego ważnych (tzw. przepustka losowa) pod konwojem funkcjonariusza Służby Więziennej, osoby godnej zaufania bądź samodzielnie na czas nieprzekraczający 5 dni (art. 141a $§ 1$ k.k.w.). Przepustka losowa może być zastosowana w stosunku do osadzonych we wszystkich typach zakładów karnych, a więc otwartych, półotwartych oraz zamkniętych. Wśród ważnych przyczyn ustawodawca wymienia odwiedzenie poważnie chorego członka rodziny, uczestnictwo w pogrzebie członka rodziny oraz inne przypadki szczególnie ważne dla skazanego. Wyrażenie „przypadki szczególnie ważne dla skazanego” stanowi pojęcie niedookreślone o charakterze ocennym. Zdarzenia te należy rozumieć

12 Zob. m.in. Europejskie Reguły Więzienne z 2006 roku - reg. 24.1-24.12, 70.1.; Rekomendacja Nr R (82) 16 Komitetu Ministrów dla państw członkowskich o czasowym opuszczaniu więzienia przyjęta przez Komitet Ministrów dnia 24 września 1982 roku, w której postuluje się o jak najczęstsze udzielanie osobom pozbawionym wolności zezwoleń na opuszczenie zakładu karnego.

13 E. Dawidziuk, op cit., s. 246. 
szeroko, włączając wszystkie szczególne sytuacje związane z warunkami rodzinnymi i osobistymi skazanego, wymagające bezwzględnie jego krótkotrwałego pobytu poza obrębem zakładu karnego ${ }^{14}$. Wśród zdarzeń tych wskazuje się przede wszystkim pogrzeb lub odwiedzenie poważnie chorej osoby najbliższej oraz tragiczne zdarzenia losowe, jak np. zniszczenie domu w wyniku powodzi. W orzecznictwie wskazuje się, iż ważną przyczyną może być również chęć ochrzczenia dziecka ${ }^{15}$. W doktrynie spotkać można stanowisko, iż w przypadku ważnej dla dziecka uroczystości rodzinnej można oprócz przepustki losowej zastosować również inne formy czasowych przepustek (np. art. 91 pkt 7 k.k.w., art. 92 pkt 9 k.k.w., art. 138 § 1 pkt 7 i 8 k.k.w.) ${ }^{16}$. Jednak zdaniem K. Postulskiego za szczególnie ważne nie mogą być uznane np. ślub dziecka lub urodzenie się dziecka, chociaż podkreśla on swoje wątpliwości w tym względzie $^{17}$. Z poglądem tym nie sposób się zgodzić. Niejednokrotnie w niniejszym opracowaniu podkreślano wagę podtrzymywania więzi rodzinnych, a uczestnictwo w tak ważnych wydarzeniach z życia najbliższych może nie tylko te więzi podtrzymać, ale również odbudować. O ile w przypadku osadzonych w zakładzie karnym typu półotwartego czy otwartego możliwe byłoby w takiej sytuacji skorzystanie np. z tzw. przepustki regulaminowej (choć też nie zawsze, nie możemy wykluczyć np. nagłego przedwczesnego porodu), to osoba osadzona w zakładzie karnym typu zamkniętego byłaby takiej możliwości pozbawiona. Z punktu widzenia zasad humanitaryzmu i poszanowania godności ludzkiej przyjęcie tego poglądu może budzić niepokój. Z aprobatą należy odnieść się do powierzenia kompetencji do udzielania tego rodzaju zezwoleń na opuszczenie zakładu karnego dyrektorowi zakładu karnego, dzięki czemu możliwa jest szybka reakcja w przypadku nagłych zdarzeń losowych. Przed podjęciem decyzji o udzieleniu komentowanego zezwolenia konieczne jest sporządzenie prognozy kryminologiczno-społecznej, która polega na pisemnym uzasadnieniu przypuszczenia, że skazany będzie podczas przepustki przestrzegał porządku prawnego ${ }^{18}$. Powinna ona zawierać między innymi analizę czynników charakteryzujących środowisko rodzinne, cechy osobowości z uwzględnieniem stopnia samodyscypliny oraz skłonności do używania przemocy, problem alkoholowy skazanego czy uzależnienie od innych substancji, zachowanie podczas uprzednio odbytych $\operatorname{kar}^{19}$. Zakres ten może być jednak zredukowany do minimum w przypad-

14 K. Postulski, Kodeks Karny Wykonawczy. Komentarz, wyd. 4, Warszawa 2017, s. 668.

15 Postanowienie SA w Lublinie z 29.11.2007 r., II AKzw 854/07, KZS 2008/4, poz. 116, LEX nr 418829 .

16 A. Kwieciński, Skazani-rodzice. Sytuacja prawna osadzonych sprawujacych opieke nad dziećmi, „Nowa Kodyfikacja Prawa Karnego”, Nr 28, 2012, s. 187.

17 K. Postulski, op. cit., s. 669.

18 L. Lachowski, Kodeks karny wykonawczy. Komentarz, wyd. 2, Warszawa 2016, s. 557.

19 Rozporządzenie Ministra Sprawiedliwości z 14 sierpnia 2003 r. w sprawie sposobów prowadzenia oddziaływań penitencjarnych w zakładach karnych i aresztach śledczych (tekst jedn. Dz.U. z 2013 r. poz. 1067), § 26. 
kach niecierpiących zwłoki. W doktrynie znaleźć można pogląd, zgodnie z którym mimo, iż przepisy nie wykluczają udzielenia zezwolenia na opuszczenie zakładu karnego skazanemu stwarzającemu poważne zagrożenie, uznać należy, że możliwość ta jest wykluczona z uwagi na warunki, w jakich kara jest wykonywana wobec tego rodzaju skazanych ${ }^{20}$. Wątpliwe wydaje się jednak całkowite pozbawianie tych osób możliwości uczestnictwa w tak znaczących dla nich wydarzeniach jak np. pogrzeb rodzica. Udzielenie zezwolenia w połączeniu z konwojowaniem najprawdopodobniej byłoby w tej sytuacji wystarczające. Warto wskazać, iż zdaniem Europejskiego Trybunału Praw Człowieka w Strasburgu ${ }^{21}$ „Organ decydujący o udzieleniu przepustki na podstawie art. 141a k.k.w. powinien rozważyć, czy odmowa w tym przedmiocie jest potrzebna w demokratycznym społeczeństwie i czy obaw związanych z zezwoleniem na opuszczenie jednostki penitencjarnej przez konkretnego osadzonego nie można wyeliminować poprzez udzielenie przepustki pod konwojem funkcjonariusza Służby Więziennej"22. W sprawie Rostkowski przeciwko Polsce Trybunał wskazał jednak, iż: „art. 8 Konwencji nie gwarantuje osadzonemu nieograniczonego prawa do zwolnienia [z zakładu karnego] celem udziału w każdym ważnym dla niego wydarzeniu. To do organów władzy należy ocena istoty takiego wniosku". Biorąc pod uwagę fakt, że mówimy tu o wyjątkowo doniosłych wydarzeniach w życiu osadzonych, należy ze szczególną ostrożnością podchodzić do ewentualnej odmowy zastosowania komentowanej przepustki. Trzeba mieć świadomość, że arbitralne podejmowanie decyzji w tym zakresie może doprowadzić do naruszenia art. 8 EKPC, przewidującego prawo do poszanowania życia prywatnego i rodzinnego ${ }^{23}$.

Niebagatelne znaczenie odgrywa także możliwość czasowego opuszczenia zakładu karnego w formie nagrody, przyznawanej niezależnie od tego w jakim typie zakładu karnego skazany odbywa karę. Zgodnie z art. 138 § 7 i 8 k.k.w. skazanym można przyznawać nagrody w formie:

- zezwolenia na widzenie bez dozoru, poza obrębem zakładu karnego z osobą najbliższą lub godną zaufania, na okres nieprzekraczający jednorazowo 30 godzin;

- zezwolenia na opuszczenie zakładu karnego bez dozoru, na okres nieprzekraczający jednorazowo 14 dni.

20 S. Lelental, Kodeks karny wykonawczy. Komentarz, wyd. 6, Warszawa 2017, s. 572.

21 Dalej: Trybunał lub ETPCz.

22 Wyrok Europejskiego Trybunału Praw Człowieka z dnia 29 listopada 2011 roku w sprawie Giszczak przeciwko Polsce, skarga nr 40195/08.

${ }_{23}$ Zob. m.in. Wyrok Europejskiego Trybunału Praw Człowieka z 20 stycznia 2009 roku w sprawie Czarnowski przeciwko Polsce, skarga nr 28586/03 oraz Wyrok Europejskiego Trybunału Praw Człowieka z 12 listopada 2002 w sprawie Płoski przeciwko Polsce, skarga nr 26761/95. 
W doktrynie określa się je jako, „przepustki nagrodowe”24. W przeciwieństwie do pozostałych nagród określonych w art. 138 k.k.w. nie mogą być one stosowane jako ulgi. W pierwszej kolejności należy odpowiedzieć sobie na pytanie kim jest wspomniana „osoba najbliższa lub osoba godna zaufania”. Przez osobę najbliższą należy rozumieć małżonka, wstępnych, zstępnych, rodzeństwo, powinowatych $\mathrm{w}$ tej samej linii lub stopniu, osobę pozostająca w stosunku przysposobienia oraz jej małżonka, a także osobę pozostającą we wspólnym pożyciu (art. 115 § 11 k.k.) natomiast osobą godną zaufania może być osoba korzystająca z pełni praw cywilnych i obywatelskich, która nie była skazana za przestępstwo popełnione umyślnie, nie została pozbawiona praw rodzicielskich lub opiekuńczych, daje rękojmię należytego wykonywania obowiązków, a także ukończyła 24 lata, a w wyjątkowych przypadkach 21 lat, jeżeli ma kwalifikacje lub doświadczenie życiowe wskazujące na przydatność w prowadzeniu działalności wychowawczej i resocjalizacyjnej ${ }^{25}$. W przypadku widzenia bez dozoru, poza obrębem zakładu karnego skazany musi uwiarygodnić, że widzenie odbędzie się ze wspomnianą uprzednio osobą najbliższą lub osobą godną zaufania. Ustawodawca wprowadził także szereg innych przesłanek, które muszą zostać spełnione, aby możliwe było udzielenie omawianych nagród. Przede wszystkim skazany musi wyróżniać się dobrym zachowaniem w czasie odbywania kary (art. 137 k.k.w.). Postawa skazanego w czasie odbywania kary ma uzasadniać przypuszczenie, że w czasie pobytu poza zakładem karnym skazany będzie przestrzegał porządku prawnego. Zgodnie z definicją słownikową, słowo „przypuszczać” oznacza - domyślać się czegoś, nie mając pewności ${ }^{26}$. Pozwala to wysnuć wniosek, że ustawodawca wziął pod uwagę, iż tego rodzaju prognoza zawsze zawiera w sobie większy lub mniejszy element ryzyka. Ryzyko to wynika głównie z faktu, że przyszłe zachowania skazanego oceniamy w oparciu o postawę reprezentowaną w innej, specyficznej i zdecydowanie różniącej się rzeczywistości²7. Wyjaśnienia wymaga również pojęcie ,porządku prawnego”. Pojęcie to rozumie się szeroko jako ogół nakazów i zakazów wynikających z przepisów prawa karnego sensu largo, prawa administracyjnego, cywilnego, rodzinnego, pracy i innych gałęzi prawa ${ }^{28}$. Wydaje się, że wymaganie to ukształtowano zbyt rygorystycznie, przede wszystkim nie wydaje się możliwe ustalenie czy osoba podczas zwolnienia przestrzegać będzie wszystkich norm każdej z wymienionych dziedzin prawa. Zgodzić należy się z G.B. Szczygieł, iż można by w tym miejscu posłużyć się ter-

24 Z. Hołda, J. Hołda, J. Migdał, B. Żórawska, Prawo karne wykonawcze, wyd. 5, Warszawa 2017, s. 235.

25 Rozporządzenie Prezesa Rady Ministrów z 28.12.2016 r. w sprawie współdziałania podmiotów w wykonywaniu kar, środków karnych, kompensacyjnych, zabezpieczających, zapobiegawczych oraz przepadku, a także społecznej kontroli nad ich wykonywaniem (Dz.U. poz. 2305), § 3.

26 Słownik języka polskiego PWN, https://sjp.pwn.pl, Dostęp: 25.03.2018.

27 G.B. Szczygieł, op. cit., s. 120.

28 Ibidem, s. 121. 
minologią analogiczną do przyjętej w przypadku warunkowego przedterminowego zwolnienia (art. 77 § 1 k.k.), a mianowicie „będzie przestrzegał porządku prawnego, w szczególności nie popełni ponownie przestępstwa" ${ }^{29}$. Obie z wymienionych nagród można przyznać po odbyciu przez skazanego co najmniej połowy tej części kary, po której mógłby być warunkowo przedterminowo zwolniony. Inaczej jest w przypadku osoby odbywającej karę dożywotniego pozbawienia wolności, w tym bowiem przypadku nagrody można przyznać dopiero po odbyciu co najmniej 15 lat kary. Takich warunków nie wprowadzono przy omówionym uprzednio zwolnieniu w wypadkach szczególnie ważnych dla skazanego, jednak tak jak uprzednio konieczne jest przeprowadzenie prognozy kryminologiczno-społecznej, z tym jednak zastrzeżeniem, że przeprowadza się ją tylko przed zaopiniowaniem wniosku o udzielenie komentowanych nagród po raz pierwszy ${ }^{30}$. Po przeprowadzeniu tej prognozy opinię w sprawach o przyznanie nagrody w postaci zezwolenia na widzenie bez dozoru, poza obrębem zakładu karnego oraz w postaci zezwolenia na opuszczenie zakładu karnego bez dozoru wyraża komisja penitencjarna (art. $76 \S$ 1 pkt 9 i 10a k.k.w.). Oczywiście Kodeks karny wykonawczy przewiduje również możliwość cofnięcia komentowanych nagród w sytuacjach, gdy pojawią się nowe okoliczności uzasadniające przypuszczenie, że skazany nie będzie przestrzegał porządku prawnego w czasie pobytu poza zakładem karnym albo jeżeli skazany zostanie zatrzymany przez uprawniony organ $w$ związku z naruszeniem przez niego porządku prawnego w czasie trwania omawianych nagród (art. 139 § 8 k.k.w.). Warto wskazać, iż zgodnie z obecnie obowiązującymi regulacjami łączna liczba nagród wymienionych w art. $138 \S 1$ pkt 7 nie może przekroczyć 28 , natomiast łączny czas trwania nagrody z art. $138 \S 1$ pkt 8 nie może przekroczyć 28 dni w roku, podczas gdy Kodeks karny wykonawczy z 1969 roku nie przewidywał tego rodzaju ograniczen ${ }^{31}$. Zakres stosowania tej nagrody został więc w znaczący sposób ograniczony. Trudno zatem znaleźć uzasadnienie dla tego rozwiązania. Na skazanym podczas przebywania poza murami zakładu karnego w ramach udzielonych nagród ciąży szereg obowiązków, wśród których znajduje się obowiązek bezzwłocznego zgłoszenia się do jednostki Policji, właściwej terytorialnie dla miejsca jego przebywania w okresie korzystania z zezwolenia, celem potwierdzenia miejsca pobytu oraz w przypadku ewentualnej zmiany miejsca pobytu, obowiązek bezzwłocznego zgłoszenia się do jednostki Policji właściwej do nowego miejsca jego przebywania, obowiązek stosowania się do wydanego przez dyrektora zakładu karnego zobowiązania do określonego zachowania się, a zwłaszcza do przebywania

29 G.B. Szczygieł, op. cit., s. 122.

30 Zob. szerzej § 25 Rozporządzenia Ministra Sprawiedliwości z 14 sierpnia 2003 r. w sprawie sposobów prowadzenia oddziaływań penitencjarnych w zakładach karnych i aresztach śledczych (tekst jedn. Dz.U. z 2013 r. poz. 1067).

31 S. Lelental, op. cit., s. 558. 
w określonych w zezwoleniu miejscach pobytu lub częstszego zgłaszania się do jednostki Policji (art. 140 k.k.w.). Co istotne, jeżeli skazany, wobec którego zastosowano komentowane nagrody nadużyje zaufania, a w szczególności nie powróci do zakładu karnego w wyznaczonym terminie zostaje pozbawiony możliwości otrzymywania omawianych nagród przez okres co najmniej 6 miesięcy od udzielenia ostatniej nagrody. Za S. Lelentalem przyjąć należy, że ze względu na konsekwencje nadużycia zaufania określone w art. $140 \S 4$ k.k.w. musi być ono wartościowane. Przede wszystkim nie do pogodzenia z tą konsekwencją byłoby uznanie za nadużycie zaufania np. opóźnienie powrotu skazanego do zakładu karnego z przyczyn od niego niezależnych ${ }^{32}$. Omówione nagrody mają ogromną wartość, a przyznawane regularnie mogą motywować więźnia do zwiększenia samokontroli w zachowaniu i w efekcie poprawić jego samosterowność. Mając powyższe na uwadze, uznać należy, że liberalizacja omówionych rozwiązań byłaby pożądana.

Omówione powyżej regulacje nie wyczerpują wszystkich możliwości kontaktów skazanych odbywających się poza murami zakładów karnych. W Kodeksie karnym wykonawczym przepustki występują także jako element wykonywania kary w zakładach półotwartych i otwartych (art. $91 \S 7$ oraz art. $92 \S 9$ k.k.w.). Przepustki te, zwane w doktrynie najczęściej systemowymi ${ }^{33}$ przyznawane są na pisemny wniosek przełożonego skazanego lub z urzędu. Różnice w postępowaniu ze skazanymi, dotyczące stopnia izolacji od świata zewnętrznego, zależą przede wszystkim od typu zakładu karnego, w którym dana osoba przebywa. Oczywiście, najwięcej dolegliwości wynika $\mathrm{z}$ faktu osadzenia w zakładzie karnym typu zamkniętego, odpowiednio mniej z faktu osadzenia w zakładzie typu półotwartego i w dalszej kolejności w zakładzie typu otwartego. Skazany odbywający karę pozbawienia wolności w zakładzie karnym typu półotwartego może otrzymać przepustki z zakładu karnego nie częściej niż raz na dwa miesiące, łącznie na okres nieprzekraczający 14 dni w roku (art. 91 pkt 7 k.k.w.), natomiast w zakładzie karnym typu otwartego skazanym można udzielać przepustek z zakładu karnego nie częściej niż raz w miesiącu, łącznie na okres nieprzekraczający 28 dni w roku. Nie wskazano maksymalnego wymiaru jednej przepustki, jednak użycie tego pojęcia w komentowanych przepisach, w liczbie mnogiej wskazuje, że nie jest możliwe udzielenie przepustki w zakładzie karnym typu półotwartego jednorazowo na 14 dni, a w zakładzie karnym typu otwartego jednorazowo na dni $28^{34}$. Koniecznie jest zatem ustawowe wypełnienie luki w tym zakresie. Kodeks w aktualnym brzmieniu nie przewiduje udzielenia tego rodzaju przepustki skazanym osadzonym w zakładzie karnym typu zamkniętego. Przesłanki formalne ukształtowane zostały podobnie jak w przypadku tzw. przepustek nagrodowych. Art. 93 k.k.w. zawiera

\footnotetext{
32 Ibidem, s.556.

33 Zob. m.in. L. Lachowski, op. cit., s. 456.

34 Ibidem, s. 454.
} 
odesłanie, stanowiące o odpowiednim stosowaniu rozwiązań, przewidzianych w poszczególnych przepisach omówionego uprzednio art. 139 k.k.w. oraz art. 140 k.k.w. Różnica między nagrodami, a omawianymi przepustkami polega przede wszystkim na tym, że te pierwsze stanowią środek oddziaływania na wszystkich skazanych, drugie natomiast są elementem wolnej progresji w odbywaniu kary. W związku z tym, że są to odrębne formy, brak jest przeciwwskazań do udzielenia ich niezależnie od siebie ${ }^{35}$.

W okresie do 6 miesięcy przed przewidywanym warunkowym zwolnieniem lub przed wykonaniem kary ustawodawca przewidział szereg działań związanych z przyszłą adaptacją społeczną skazanego, które ten może realizować z pomocą administracji zakładu karnego oraz przy odpowiednim wsparciu z zewnątrz (art. $164 \S 1)$. Nie jest to jednak instytucja obligatoryjna, gdyż może się okazać, że skazany posiada odpowiednie warunki przyszłej adaptacji, przez co wyznaczenie okresu przygotowania jawi się jako zbędne ${ }^{36}$. O zezwoleniu na opuszczenie zakładu karnego udzielanym przed końcem kary stanowi art. 165 k.k.w. Zgodnie z § 2 przywołanego przepisu skazanemu można zezwolić na opuszczenie zakładu karnego na czas do 14 dni, zwłaszcza w celu podejmowania starań o uzyskanie po zwolnieniu odpowiednich możliwości zamieszkania oraz pracy. Użycie sformułowania „Zwłaszcza” wskazuje na to, że mogą to być również inne przyczyny. Zezwolenie na opuszczenie zakładu karnego można przyznać skazanemu, którego postawa w czasie odbywania kary uzasadnia przypuszczenie, że w czasie pobytu poza zakładem karnym będzie przestrzegał porządku prawnego (art. $165 \S 2 \mathrm{zd}$. 2 k.k.w.). Zgodzić się należy z G. Wicińskim, że jest to rozwiązanie wątpliwe w sytuacji, gdy rozważana jest przepustka przed warunkowym przedterminowym zwolnieniem. W takiej bowiem sytuacji pozytywna prognoza wynika już z samej istoty tego faktu ${ }^{37}$. Na marginesie wskazać należy, że podczas komentowanego zezwolenia na opuszczenie zakładu karnego na skazanym również ciążą obowiązki wynikające z art. 140 k.k.w., a poruszany wcześniej przepis art. 139 § 8 k.k.w., dotyczący cofnięcia udzielonego zezwolenia na opuszczenie zakładu karnego znajduje w tym przypadku odpowiednie zastosowanie.

Nie bez znaczenia pozostają także możliwości udzielenia skazanemu zezwolenia na uczestnictwo w nauczaniu, szkoleniu, zajęciach terapeutycznych, kulturalno -oświatowych lub sportowych organizowanych poza terenem zakładu zamkniętego (zob. m.in. art. 92 pkt 3, 4 i 5, art. 130 § 5 oraz art. 131 k.k.w.).

35 K. Postulski, op. cit., s. 561.

36 Postanowienie Sądu Apelacyjnego w Krakowie z 16 czerwca 1999 roku, II AKz 269/99.

37 G. Wiciński, Instytucjonalne formy kontaktów ze światem zewnętrznym osób odbywających karę pozbawienia wolności, [w] Aktualne problemy prawa karnego, kryminologii i penitencjarystyki. Księga ofiarowana Profesorowi Stanisławowi Lelentalowi, Łódź 2004, s. 515. 
Należy zatrzymać się na nad jeszcze jedną istotną kwestią, a mianowicie nad niebezpieczeństwem wynikającym z udzielania przepustek bądź zezwoleń na czasowe opuszczenie zakładu karnego. Na pierwszy plan wysuwa się ryzyko nieterminowego powrotu do zakładu karnego czy niepowrócenie do zakładu karnego lub aresztu śledczego w ogóle, co stanowi przestępstwo z art. $242 \S 2$ k.k. ${ }^{38}$. Możliwe jest też nieodpowiednie zachowanie podczas pobytu na wolności jak np. nadużywanie alkoholu. W skrajnych przypadkach - popełnienie nowego przestępstwa, co zdarza się jednak niezmiernie rzadko. $Z$ reguły są to czyny przeciwko mieniu czy naruszenie bezpieczeństwa w komunikacji. Z tego względu możliwość udzielania przepustek obwarowana jest licznymi ograniczeniami, które zostały już wyżej przy konkretnych rozwiązaniach wyszczególnione. Warto jednak wskazać, że ryzyko naruszenia porządku prawnego najczęściej podczas pobytu poza murami zakładu karnego jest niewielkie. Dodatkowo przeprowadzenie trafnej prognozy je zmniejsza. Biorąc te okoliczności pod uwagę, zdaje się, że niektóre rozwiązania są zbyt restrykcyjne, gdyż za bardzo zmniejszają możliwości zachowania łączności skazanych ze światem zewnętrznym. Biorąc pod uwagę ogólny bilans zysków i strat, a przede wszystkim fakt, że więzień, który ma możliwość okresowego opuszczania jednostki penitencjarnej ma szansę zniwelowania przynajmniej niektórych problemów, będących naturalnymi konsekwencjami izolacji, z pewnością należy stwierdzić, że jeżeli to tylko możliwe, więzień powinien otrzymywać przepustki do domu regularnie, a kryteria ich udzielania powinny podlegać przejrzystym zasadom. Arbitralne decyzje o zastosowaniu bądź niezastosowaniu przepustek więziennych mogą wywołać w odczuciu osadzonych poczucie niesprawiedliwości. Nie jest łatwe ocenienie zmian w osobowości skazanego w czasie pobytu w zakładzie karnym, dlatego poddawanie skazanego swoistej próbie poprzez czasowe zezwolenia na opuszczenie zakładu karnego pozwoli na obiektywne stwierdzenie czy sprawca potrafi funkcjonować poza zakładem karnym w zgodzie z regułami przyjętymi w społeczeństwie, co w konsekwencji będzie można uwzględnić rozważając ewentualne warunkowe przedterminowe zwolnienie. Biorąc pod uwagę nieuniknione podczas odbywania kary pozbawienia wolności w obecnym systemie prawnym osłabienie więzi z bliskimi, należy stosować mechanizmy, które będą pozwalały na udzielanie przepustek jak najwcześniej i tak często jak to tylko możliwe. Doniosłość komentowanych instytucji polega na doprowadzeniu do zaspokojenia potrzeb skazanego w kontakcie z innymi osobami, a jednocześnie podtrzymaniu łączności

38 Zob. szerzej. P. Daniluk, O przestępstwach samouwolnienia się osoby pozbawionej wolności (art. $242 \xi 1$ i 4 k.k.) oraz niepowrotu osoby pozbawionej wolności do zaktadu karnego lub aresztu śledczego (art. 242 § 2 i 3 k.k.), [w:] Pozbawienie wolności - funkcje i koszty. Księga Jubileuszowa Profesora Teodora Szymanowskiego, pod red. A. Rzepliński, P. Wiktorska, I. Rzeplińska, M. Niełaczna, Warszawa 2013. 
ze społeczeństwem, co było już wielokrotnie podkreślane ${ }^{39}$. Nagrody te stanowią również sui generis sprawdzian dla skazanego do życia poza nadzorem, co wydaje się szczególnie wartościowe. Omówionych kontaktów z pewnością nie są w stanie zapewnić listy czy widzenia. Tylko realny kontakt z rzeczywistością poza murami zakładu karnego pozwoli odpowiednio przygotować się przez skazanego do jego opuszczenia. Tylko w ten sposób skazany może nauczyć się zachowań, których w zakładzie karnym nie doświadczy. Żeby nauczyć kogoś życia na wolności, należy mu przynajmniej namiastkę tej wolności zapewnić.

\section{PODSUMOWANIE}

Zmierzając ku końcowi przedstawionych uwag celowe jest zastanowienie się nad liberalizacją przynajmniej niektórych z omówionych rozwiązań. Utrzymywanie kontaktów z rodziną i światem zewnętrznym jest wyjątkowo ważnym środkiem oddziaływania penitencjarnego, co zostało wyżej wykazane. Ważne więc, by podejmować próby wprowadzania rozwiązań, które w coraz to doskonalszy sposób będą niwelować negatywne aspekty kary pozbawienia wolności. Do najważniejszych tego rodzaju działań należy zaliczyć m.in. omówione w niniejszym opracowaniu, wybrane formy kontaktów zewnętrznych. Może należałoby w ślad za innymi krajami Europy oraz standardami wynikającymi z aktów międzynarodowych rozszerzyć system przepustek i zezwoleń na czasowe opuszczenie zakładu karnego przez skazanych między innymi w stosunku do więźniów odbywających karę w zakładach typu zamkniętego ${ }^{40}$. Warto w tym względzie wskazać, że odsetek niepowodzeń polegających na spóźnionych powrotach oraz tzw. niepowrotach wbrew powszechnym przekonaniom jest znikomy. W latach 1991-2015 kwestia ta przedstawiała się wyjątkowo korzystnie. Jeżeli chodzi o problem tzw. niepowrotów to ich odsetek spadał z $6,3 \%$ do $0,5 \%-0,0 \%$ w ostatnich latach ${ }^{41}$. Zważywszy na powyższe, trudno nie podzielić poglądu T. Szymanowskiego, zgodnie z którym ów stan rzeczy można wiązać ze zmniejszającymi się niepowodzeniami w rozszerzaniu kontaktów skazanych. Biorąc powyższe pod uwagę, trudno znaleźć uzasadnienie dla zauważalnego w ostatnich latach zmniejszenia się liczby udzielonych zezwoleń m.in. w przypadku zezwoleń na czasowe opuszczenie zakładu karnego w formie nagród oraz w przypadku tzw. przepustek losowych. Jak pokazują statystyki, liczba wszystkich przepustek i zezwoleń, która w 2014 roku wynosiła blisko 199 tysięcy,

39 T. Szymanowski, op. cit., s. 357.

${ }^{40}$ M. Niedbała, Czasowe opuszczenie zakładu karnego forma przygotowania skazanego do wolności? http://www.publikacje.edu.pl/publikacje.php?nr=9853 Dostęp: 23.02.2018.

41 T. Szymanowski, op. cit., s. 324. 
spadła w latach 2016 i 2017 roku poniżej 150 tysięcy ${ }^{42}$. Istotnym argumentem przemawiającym za rozszerzeniem możliwości szeroko rozumianego opuszczania murów zakładu karnego w trakcie odbywania kary izolacyjnej jest fakt, że same kontakty pośrednie mogą skutkować tym, że więźniowie będą nieprzygotowani do prawdziwego świata, z którym przyjdzie im się zmierzyć, gdy zostaną zwolnieni z zakładu karnego. Brak bezpośredniego dostępu do świata zewnętrznego może doprowadzić do tego, że skazani - w erze postępującej technologii i wszechobecnych zmian - będą zupełnie nieporadni życiowo. W kontekście zaś omówionych już więzi rodzinnych, warto przypomnieć, iż ich zerwanie może powodować potęgowanie się trudności w odnalezieniu się w społeczeństwie. Jak już wskazano - aby więź rodzinna mogła przetrwać - musi być podtrzymywana. Możliwość czasowego opuszczenia jednostki penitencjarnej przyczynia się także do zniwelowania innych problemów wynikających z faktu pozbawienia wolności np. problemów natury seksualnej oraz związanych z relacjami pomiędzy skazanymi a ich partnerami, a ponadto daje skazanemu poczucie stabilizacji, które z pewnością pomoże w sposób aktywny i odpowiedzialny budować podstawy życia na wolności. Nie należy zapominać, że znaczny procent skazanych wróci do życia na wolności. Od tego czy będą umieli się tam odnaleźć zależy nie tylko ich przyszłość, ale także bezpieczeństwo społeczeństwa, w którym przyjdzie im po opuszczeniu zakładu karnego funkcjonować. Mając na uwadze wskazane już liczne zalety podtrzymywania kontaktów ze światem zewnętrznym w tym m.in. rodziną i bliskimi potencjał jak najczęstszego opuszczania murów zakładu karnego jest niekwestionowany. Poszanowanie życia rodzinnego z pewnością jest jednym ze skuteczniejszych środków do osiągnięcia podstawowych celów kary pozbawienia wolności, w tym przede wszystkim społecznej readaptacji skazanych. Dotychczasowa praktyka w zakresie prawa do poszanowania życia rodzinnego osób pozbawionych wolności wciąż wymaga poprawy ${ }^{43}$.

Przedstawiona w niniejszym artykule analiza dotycząca kontaktów skazanych ze światem zewnętrznym pozwala wysnuć wniosek, iż z uwagi na doniosłość omówionego zagadnienia konieczne zdaje się przeprowadzenie szczegółowych badań oraz przedstawienie kompleksowego opracowania dotyczącego kontaktów skazanych ze światem zewnętrznym - zarówno pośrednich, jak i bezpośrednich, co pozwoli na opracowanie optymalnej regulacji, adekwatnej do aktualnego stanu wiedzy w tej wyjątkowo delikatnej materii. Trzeba mieć na uwadze, że pojedyn-

42 Źródło: Centralny Zarząd Stużby Więziennej.

43 Zob. Opinia Helsińskiej Fundacji Praw Człowieka z 14 stycznia 2016 roku i powołane tam orzecznictwo: m. in. Wyrok z 29 listopada 2011 r. w sprawie Giszczak przeciwko Polsce (skarga nr 40195/08), Wyrok z 11 października 2005 r. w sprawie Bagiński przeciwko Polsce (skarga nr 37444_97), Wyrok z 3 kwietnia 2003 roku w sprawie Klamecki przeciwko Polsce (skarga nr 31583/96), Wyrok z 20 stycznia 2009 r. w sprawie Czarnowski przeciwko Polsce (skarga nr 28586_03). 
cze sytuacje naruszeń ze strony skazanych podczas m.in. udzielanych przepustek nie mogą stanowić podstawy do generalnego ich kwestionowania. System trzeba poprawiać analizując dotychczasowe błędy, co potwierdza konieczność przeprowadzenia szczegółowych badań w tym zakresie. Zgadzam się z Rzecznikiem Praw Obywatelskich, że bez systemu przepustkowego wszyscy bylibyśmy mniej bezpieczni, gdyż „Zero przepustek to zero ryzyka w trakcie kary i ogromne ryzyko po jej odbyciu" ${ }^{4}$.

\section{BIBLIOGRAFIA}

Daniluk P., O przestępstwach samouwolnienia się osoby pozbawionej wolności (art. 242 § 1 i 4 k.k.) oraz niepowrotu osoby pozbawionej wolności do zakładu karnego lub aresztu śledczego (art. 242 § 2 i 3 k.k.), [w:] Pozbawienie wolności - funkcje i koszty. Księga Jubileuszowa Profesora Teodora Szymanowskiego, pod red. A. Rzepliński, P. Wiktorska, I. Rzeplińska, M. Niełaczna, Warszawa 2013.

Dawidziuk E., Traktowanie osób pozbawionych wolności we współczesnej Polsce na tle standardów międzynarodowych, Warszawa 2013.

Hołda Z., Hołda J., Migdał J., Żórawska B., Prawo karne wykonawcze, wyd. 5, Warszawa 2017.

Kwieciński A., Skazani-rodzice. Sytuacja prawna osadzonych sprawujących opiekę nad dziećmi, „Nowa Kodyfikacja Prawa Karnego”, 2012, Nr 28, s. 187.

Lachowski L. Kodeks karny wykonawczy. Komentarz, wyd. 2, Warszawa 2016.

Lelental. S., Kodeks karny wykonawczy. Komentarz, wyd. 6, Warszawa 2017.

Linowski K., Możliwości rozwoju człowieka w warunkach izolacji penitencjarnej poprzez utrzymanie kontaktów zewnętrznych, Acta Scientifica Academiae Osrtoviensis, „Prace Pedagogiczne”, 8/ 2001.

Machel H., Rodzina skazanego jako współuczestnik jego resocjalizacji penitencjarnej, readaptacji i reintegracji społecznej, ,Resocjalizacja Polska”, nr 7, 2014.

Niedbała M., Czasowe opuszczenie zakładu karnego formą przygotowania skazanego do wolności? http://www.publikacje.edu.pl/publikacje.php?nr=9853 Dostęp: 27 marca 2017.

Postanowienie Sądu Apelacyjnego w Krakowie z 16 czerwca 1999 roku, II AKz 269/99.

Postulski K., Kodeks Karny Wykonawczy. Komentarz, wyd. 4, Warszawa 2017.

Rekomendacja Nr R (82) 16 Komitetu Ministrów dla państw członkowskich o czasowym opuszczaniu więzienia przyjęta przez Komitet Ministrów dnia 24 września 1982 roku.

Rozporządzenie Ministra Sprawiedliwości z 14 sierpnia 2003 r. w sprawie sposobów prowadzenia oddziaływań penitencjarnych w zakładach karnych i aresztach śledczych (tekst jedn. Dz.U. z 2013 r. poz. 1067).

Rozporządzenie Prezesa Rady Ministrów z 28 grudnia 2016 r. w sprawie współdziałania podmiotów w wykonywaniu kar, środków karnych, kompensacyjnych, zabezpieczających, zapobiegawczych oraz przepadku, a także społecznej kontroli nad ich wykonywaniem (Dz.U. poz. 2305).

Rzepliński A., Rodziny Więźniów długoterminowych, Instytut Państwa i Prawa, Wrocław 1981.

Rzepliński A., Wpływ wykonywania kary pozbawienia wolności na sytuację rodzinną skazanego, Warszawa 1978.

44 Oświadczenie RPO z 11 września 2018 roku w związku z nagłośnioną w mediach sprawą Artura K. https://www.rpo.gov.pl/pl/content/przepustki-dla-wiezniow-oswiadczenie-RPO Dostęp: 17.06.2019. 
Sarzała D., Rodzina osoby przebywającej w izolacji więziennej jako środowisko wsparcia społecznego, „Kwartalnik Naukowy”, 4(28)2016.

Stańdo-Kawecka B., Pukanie do celi, „Forum Penitencjarne”, Nr 1, 2006.

Szczygieł G.B., Zezwolenie na czasowe opuszczenie zakładu karnego w polskim systemie penitencjarnym, Białystok 2013.

Szymanowski T., Prawo karne wykonawcze z elementami polityki karnej i penitencjarnej, Warszawa 2017.

Ustawa z dnia 6 czerwca 1997 r. - Kodeks karny (Dz.U. z 2017 r., poz. 2204).

Ustawa z dnia 6 czerwca 1997 r. - Kodeks karny wykonawczy (Dz.U. z 2017 r., poz. 665 z późn. zm.).

Wiciński G., Instytucjonalne formy kontaktów ze światem zewnętrznym osób odbywających karę pozbawienia wolności, [w] Aktualne problemy prawa karnego, kryminologii i penitencjarystyki. Księga ofiarowana Profesorowi Stanisławowi Lelentalowi, Łódź 2004.

Wolińska P., Znaczenie instytucji rodziny w życiu osób odbywających karę pozbawienia wolności, „Rozprawy Społeczne”, Tom X, Nr 2, 2016.

Wyrok Europejskiego Trybunału Praw Człowieka z 12 listopada 2002 w sprawie Płoski przeciwko Polsce, skarga nr 26761/95.

Wyrok Europejskiego Trybunału Praw Człowieka z 20 stycznia 2009 roku w sprawie Czarnowski przeciwko Polsce, skarga nr 28586/03.

Wyrok Europejskiego Trybunału Praw Człowieka z dnia 29 listopada 2011 roku w sprawie Giszczak przeciwko Polsce, skarga nr 40195/08.

Zalecenia Rec (2006)2 Komitetu Ministrów do państw członkowskich Rady Europy w sprawie Europejskich Reguł Więziennych przyjęte przez Komitet Ministrów w dniu 11 stycznia 2006 roku.

\section{SUMMARY}

The purpose of this article is to analyze some normative solutions included in currently applicable Executive Penal Code, which ensure that prisoners sustain contact with the outside world. From among the entire range of instruments, the ones that allow a convict to leave prison walls were discussed. The role of sustaining contact with outside world, with particular emphasis on family ties, was also analyzed. Potential threats resulting from granting of passes or permits to temporarily leave the prison were also indicated, which allowed to formulate de lege ferenda postulates.

Keywords: prisoners; penitentiary; contact with the outside world. 